\title{
Effect of Seed Treatments with Neonicotinoids on Maize Inbred Lines Seed Quality
}

\author{
Gordana Tamindžić • Zorica Nikolić • Raško Popov • Dušica Jovičić • \\ Gordana Zdjelar • Vesna Župunski • Maja Ignjatov
}

\author{
received: 1 November 2013, accepted: 11 December 2013 \\ published online: 20 January 2014 \\ (c) 2013 IFVC \\ doi: $10.5937 /$ ratpov50-4792
}

\begin{abstract}
Summary: The importance of uniform germination and field emergence for achieving high yields, while ensuring good seed quality, raises the question of the influence of fungicide and insecticide preparations for seed treatment. The aim of this study was to determine the effect of the combination of five insecticides and fungicide preparations on germination energy and germination of four maize inbred lines. The impact of applied preparations on seed quality may vary, depending on the genetic composition of maize inbred lines. Inbred line L-1 was distinguished as the most tolerant, considering the fact that significant differences were not observed in all tested preparations, while the most sensitive genotype, inbred line L-4, showed a significant decrease in germination energy and seed germination when treated with fludioxonil+metalaxyl-M (M), fludioxonil+metalaxyl-M and imidacloprid $(M+G)$, fludioxonil+metalaxyl-M and thiametoxam $(\mathrm{M}+\mathrm{Cr})$ and fludioxonil+metalaxyl-M and tefluthrin+thiametoxam $(\mathrm{M}+\mathrm{FZ})$. Results of this study indicate the importance of choosing the best combination of pesticides for certain genotypes, in order to ensure full protection of crops and at the same time obtain the high yields.

Keywords: fungicides, germination, insecticides, maize, maize inbred lines, neonicotinoids, seed treatment, seeds
\end{abstract}

\section{Introduction}

Maize production is threatened by a large number of pests throughout the growing season. Wireworms, cutworms and other larvae in the soil can be a very important, if not a limiting factor in achieving high yields. Control of these insects is usually achieved by applying chemical treatments (Sekulić et al. 2005).

Modern agriculture is inconceivable without the use of pesticides. The complete protection of seeds is provided when pesticides are used as seed treatment. The previous literature emphasizes success in the use of pesticides with respect to the uniform germination and normal seedling development (Bradley et al. 2001, Galli et al. 2005, Govender 2008). According to Bradley (2008), fungicide seed treatments have increasingly been used and the effect of

G. Tamindžićc • Z. Nikolić • R. Popov • D. Jovičić • G. Zdjelar • V. Župunski • M. Ignjatov

Institute of Field and Vegetable Crops, Maksima Gorkog 30, 21000 Novi Sad, Serbia

e-mail: gordana.mandic@gmail.com these preparations is best seen in years when environmental conditions are optimal for the development of certain pathogens. In Serbia seed treatments with fungicides are obligatory for all seed producers. Maize seed treatment with insecticides in Serbia is a relatively new method, but it has become a common practice applied to large amount of seed (Jocković et al. 2011). The main prerequisite for high quality production is seed with high germination and vigour. From the agronomic point of view, quick and uniform germination is very important for achieving high yields of good quality seed.

The aim of this study was to determine whether seed treatment with fungicide and insecticides affects germination energy and germination of maize inbred lines, considering their varietal susceptibility.

\section{Acknowledgements:}

This study as a part of a scientific project „Improvement of maize and sorghum under stress" (TR 31073) is supported by the Ministry of Education, Science and Technological Development of the Republic of Serbia. 


\section{Materials and Methods}

The effects of preparations Maxim XL 035FS, Poncho 600-FS, Gaucho 600-FS, Cruiser $350-F S$, Force Zea 280-FS and Cosmos 500-FS on the seed quality of maize inbred lines L-1 (568 NS), L-2 (23 NS), L-3 (20 NS) and L-4 (732 NS) were tested in Laboratory for Seed Testing at the Institute of Field and Vegetable Crops, Novi Sad, Serbia during 2010. The inbred lines used in this study were developed at the Institute of Field and Vegetable Crops in Novi Sad, Serbia. Untreated seeds were used as the control. All seeds were treated with fungicide fludioxonil+metalaxyl-M (preparation Maxim XL 035-FS), and the following insecticides: clothianidin (preparation Poncho 600-FS), imidacloprid (preparation Gaucho 600-FS), thiametoxam (preparation Cruiser 350-FS), tefluthrin+thiametoxam (preparation Force Zea 280-FS), and fipronil (preparation Cosmos 500-FS) at recommended doses (Table 1):

1. Control (untreated seed)

2. Fludioxonil+metalaxyl-M (M)

3. Fludioxonil+metalaxyl-M and clothianidin $(\mathrm{M}+\mathrm{P})$,

4. Fludioxonil + metalaxyl-M and imidacloprid $(\mathrm{M}+\mathrm{G})$

5. Fludioxonil+metalaxyl-M and thiametoxam $(\mathrm{M}+\mathrm{Cr})$

6. Fludioxonil+metalaxyl-Mandtefluthrin+thiametoxam $(\mathrm{M}+\mathrm{FZ})$ and

7. Fludioxonil+metalaxyl-M and fipronil $(\mathrm{M}+\mathrm{Co})$.
Upon seed treatment the germination energy and seed germination were determined by using standard germination test. Working sample consisted of $4 \times 100$ seeds which were randomly selected. Sterilized sand was used as the substrate. Seeds were incubated in a germination chamber at $25^{\circ} \mathrm{C}$ for seven days (ISTA 2009). Germination energy was determined 4 days after sowing, while seed germination and the percentage of abnormal seedlings were determined 7 days after sowing. According to ISTA (2009), seedlings were classified as abnormal in the following cases: if any of the essential structures were missing or so badly and irreparably damaged that the balanced development cannot be expected; or with weak development or physiological disturbances, or in which essential structures are deformed or out of proportion; or so diseased or decayed in any of their essential structures as a result of primary infection that the normal development is prevented. Shoot and root length of seedlings and the mass of fresh shoot and root of seedlings were also determined 7 days after sowing.

The statistical analyses were conducted by using different software packages. Analysis of variance (One-Way ANOVA) was conducted using software Genstat Release 9.1. (Rothamsted Experimental Station), while the differences between treatments by Duncan's multiple range test was conducted using software Statistica 8 (StatSoft Inc. 2007).

Table 1. Characteristics of preparations and their use Tabela 1. Karakteristike preparata i njihova upotreba

\begin{tabular}{|c|c|c|c|}
\hline $\begin{array}{l}\text { Preparations } \\
\text { Preparati }\end{array}$ & $\begin{array}{l}\text { Active matter }(\mathrm{g} / \mathrm{l}) \\
\text { Aktivne materije }(\mathrm{g} / \mathrm{l})\end{array}$ & $\begin{array}{l}\text { Applied dose } \\
\text { (ml/100kg) } \\
\text { Primenjene doze } \\
\text { (ml/100kg) }\end{array}$ & $\begin{array}{c}\text { Target group } \\
\text { Spektar delovanja }\end{array}$ \\
\hline Poncho 600-FS & $\begin{array}{l}\text { Clothianidin } 600 \\
\text { Klotianidin } 600\end{array}$ & 280 & \multirow{5}{*}{$\begin{array}{l}\text { Soil pests } \\
\text { Zemljišne } \\
\text { štetočine }\end{array}$} \\
\hline Gaucho 600-FS & $\begin{array}{l}\text { Imidacloprid } 600 \\
\text { Imidakloprid } 600\end{array}$ & 600 & \\
\hline Cruiser 350-FS & $\begin{array}{l}\text { Thiametoxam } 350 \\
\text { Tiametoksam } 350\end{array}$ & 900 & \\
\hline Force Zea 280-FS & $\begin{array}{l}\text { Tefluthrin+thiametoxam } 80+200 \\
\text { Teflutrin+tiametoksam } 80+200\end{array}$ & 420 & \\
\hline Cosmos 500-FS & Fipronil 500Fipronil 500 & 400 & \\
\hline Maxim XL 035-FS & $\begin{array}{l}\text { Metalaxyl-M+fludioxonil10+25 } \\
\text { Metalaksil-M+Fludioksonil 10+25 }\end{array}$ & $100^{*}$ & $\begin{array}{l}\text { Fusarium spp. } \\
\text { Phytium spp. }\end{array}$ \\
\hline
\end{tabular}




\section{Results}

Seeds of maize inbred lines included in this study had the high germination energy (Table 2). All preparations applied on seeds of inbred line L-1 showed no significant differences in the germination energy compared to control. The seed of inbred lines L-2 treated with fludioxonil+metalaxyl-M and tefluthrin+thiametoxam $(\mathrm{M}+\mathrm{FZ})$ had the reduced germination energy. Significant reduction in germination energy was observed in seeds of inbred lines L-3 treated with fludioxonil+metalaxyl-M (M), and fludioxonil+metalaxyl-M and imidacloprid $(\mathrm{M}+\mathrm{G})$. Reduced germination energy was also observed in seed of inbred lines L-4 treated with fludioxonil+metalaxyl-M (M), fludioxonil+metalaxyl-M and imidacloprid $(\mathrm{M}+\mathrm{G})$, and fludioxonil+metalaxyl-M and tefluthrin+thiametoxam $(\mathrm{M}+\mathrm{FZ})$.

Seed germination of maize inbred lines ranged between $93.00 \%$ and $98.75 \%$ in the control (Table 3). All applied preparations had no significant effect on the germination of seed of inbred line L-1. A significant reduction in germination was observed in seeds of inbred line L-2 treated with fludioxonil+metalaxyl-M and tefluthrin +thiamethoxam (M+FZ) (87.25\%). Seed of inbred line L-3 treated with fludioxonil+metalaxyl-M (M) $(91.50 \%)$, and fludioxonil+metalaxyl-M and imidacloprid

Table 2. Energy of germination (\%) of maize inbred lines seed treated with insecticides and a fungicide

Tabela 2. Energija (\%) klijanja semena inbred linija kukuruza tretiranih insekticidima i fungicidom

\begin{tabular}{ccccc}
\hline $\begin{array}{c}\text { Germination energy (\%) } \\
\text { Energija klijanja (\%) }\end{array}$ & $\begin{array}{c}\text { Inbred line L-1 } \\
\text { Inbred linija L-1 }\end{array}$ & $\begin{array}{c}\text { Inbred line L-2 } \\
\text { Inbred linija L-2 }\end{array}$ & $\begin{array}{c}\text { Inbred line L-3 } \\
\text { Inbred linija L-3 }\end{array}$ & $\begin{array}{c}\text { Inbred line L-4 } \\
\text { Inbred linija L-4 }\end{array}$ \\
\hline Control/Kontrola & $93.00 \mathrm{ab}$ & $97.75 \mathrm{a}$ & $96.25 \mathrm{a}$ & $98.25 \mathrm{a}$ \\
$\mathrm{M}$ & $90.25 \mathrm{~b}$ & $98.25 \mathrm{a}$ & $91.25 \mathrm{bc}$ & $86.75 \mathrm{~b}$ \\
$\mathrm{M}+\mathrm{P}$ & $95.50 \mathrm{a}$ & $95.75 \mathrm{a}$ & $96.00 \mathrm{a}$ & $96.00 \mathrm{a}$ \\
$\mathrm{M}+\mathrm{G}$ & $95.50 \mathrm{a}$ & $96.50 \mathrm{a}$ & $89.25 \mathrm{c}$ & $85.50 \mathrm{~b}$ \\
$\mathrm{M}+\mathrm{Cr}$ & $95.25 \mathrm{ab}$ & $96.50 \mathrm{a}$ & $99.75 \mathrm{a}$ & $90.75 \mathrm{~b}$ \\
$\mathrm{M}+\mathrm{FZ}$ & $94.50 \mathrm{ab}$ & $86.75 \mathrm{~b}$ & $97.25 \mathrm{a}$ & $88.75 \mathrm{~b}$ \\
$\mathrm{M}+\mathrm{Co}$ & $96.75 \mathrm{a}$ & $97.00 \mathrm{a}$ & $95.25 \mathrm{ab}$ & $99.00 \mathrm{a}$ \\
\hline $\mathrm{LSD}$ & 4.35 & 2.75 & 3.69 & 4.37 \\
\hline
\end{tabular}

Table 3. Seed germination (\%) of maize inbred lines seed treated with insecticides and a fungicide Tabela 3. Klijavost (\%) semena inbred linija kukuruza tretiranih insekticidima i fungicidom

\begin{tabular}{ccccc}
\hline $\begin{array}{c}\text { Seed germination (\%) } \\
\text { Klijavost (\%) semena }\end{array}$ & $\begin{array}{c}\text { Inbred line } \\
\text { L-1 } \\
\text { Inbred linija L-1 }\end{array}$ & $\begin{array}{c}\text { Inbred line L-2 } \\
\text { Inbred linija L-2 }\end{array}$ & $\begin{array}{c}\text { Inbred line L-3 } \\
\text { Inbred linija L-3 }\end{array}$ & $\begin{array}{c}\text { Inbred line L-4 } \\
\text { Inbred linija L-4 }\end{array}$ \\
\hline Control/Kontrola & $93.50 \mathrm{ab}$ & $97.75 \mathrm{a}$ & $97.00 \mathrm{a}$ & $98.75 \mathrm{a}$ \\
$\mathrm{M}$ & $90.25 \mathrm{~b}$ & $98.50 \mathrm{a}$ & $91.50 \mathrm{bc}$ & $86.75 \mathrm{bc}$ \\
$\mathrm{M}+\mathrm{P}$ & $95.75 \mathrm{a}$ & $96.00 \mathrm{a}$ & $96.75 \mathrm{a}$ & $97.50 \mathrm{a}$ \\
$\mathrm{M}+\mathrm{G}$ & $95.50 \mathrm{a}$ & $96.75 \mathrm{a}$ & $89.75 \mathrm{c}$ & $87.50 \mathrm{c}$ \\
$\mathrm{M}+\mathrm{Cr}$ & $95.75 \mathrm{a}$ & $96.75 \mathrm{a}$ & $99.75 \mathrm{a}$ & $95.75 \mathrm{~b}$ \\
$\mathrm{M}+\mathrm{FZ}$ & $94.50 \mathrm{ab}$ & $87.25 \mathrm{~b}$ & $97.75 \mathrm{a}$ & $89.25 \mathrm{bc}$ \\
$\mathrm{M}+\mathrm{Co}$ & $97.25 \mathrm{a}$ & $97.25 \mathrm{a}$ & $95.50 \mathrm{ab}$ & $99.50 \mathrm{ab}$ \\
\hline LSD & 4.43 & 3.09 & 3.87 & 3.41 \\
\hline
\end{tabular}


$(\mathrm{M}+\mathrm{G}) \quad(89.75 \%)$ had the reduced seed germination compared to control. Seed of inbred line L- 4 proved to be more sensitive when treated with fludioxonil+metalaxyl-M (M) (86,75\%), fludioxonil+metalaxyl-M and imidacloprid $(\mathrm{M}+\mathrm{G})(87.50 \%)$, fludioxonil + metalaxyl-M and tefluthrin+thiametoxam (M+FZ) $(89.25 \%)$ and with fludioxonil+metalaxyl-M and thiametoxam $(\mathrm{M}+\mathrm{Cr})(95.75 \%)$. Seed germination of inbred line L-4 treated with fludioxonil+metalaxyl-M (M), fludioxonil+metalaxyl-M and imidacloprid $(\mathrm{M}+\mathrm{G})$, and fludioxonil+metalaxyl-M and tefluthrin+thiametoxam (M+FZ) was below the limit $(90 \%)$ according to the Rules on Seed Quality of Agricultural Plants (SFRY 1987).

Abnormal seedlings are all seedlings with no specific combination of certain structures necessary for growth and development under favourable environmental conditions (Stevanović et al. 2009). The smallest percentage of abnormal seedlings in the control of inbred line L-4 (0.5\%) was observed, while the largest percentage of abnormal seedlings was observed in the control of inbred line L-1 $(2.75 \%)$ as shown in Table 4. Seed of inbred line L-3 treated with fludioxonil+metalaxyl-M and imidacloprid $(\mathrm{M}+\mathrm{G})(8.75 \%)$ had a significantly greater percentage of abnormal seedling compared to control. The significant increase of abnormal seedlings $(8.75 \%)$ was observed in the inbred line L-3 treated with fludioxonil+metalaxyl-M and imidacloprid $(\mathrm{M}+\mathrm{G})$. Inbred line $\mathrm{L}-4$ was also sensitive $(12.50 \%)$ to the application of fludioxonil+metalaxyl-Mand imidacloprid $(\mathrm{M}+\mathrm{G})$, fludioxonil+metalaxyl-M and thiametoxam $(\mathrm{M}+\mathrm{Cr})(4.25 \%)$ and fludioxonil+metalaxyl-M and tefluthrin+thiametoxam (M+FZ) $(7.50 \%)$.
Shoot length of seedlings of maize inbred lines ranged between $111.3 \mathrm{~mm}$ and 173.0 $\mathrm{mm}$ in control (Table 5). Seed of inbred line L-1 treated with fludioxonil+metalaxyl-M and clothianidin $(\mathrm{M}+\mathrm{P})(166.4 \mathrm{~mm})$ had significantly greater shoot length of seedlings. Seed of inbred line L-2 treated with fludioxonil+metalaxyl-M (M), fludioxonil+metalaxyl-M and clothianidin $(\mathrm{M}+\mathrm{P})$, fludioxonil+metalaxyl-M and imidacloprid $(\mathrm{M}+\mathrm{G})$, fludioxonil+metalaxyl-M and thiametoxam $(\mathrm{M}+\mathrm{Cr})$, and fludioxonil+metalaxyl-M and tefluthrin+thiametoxam (M+FZ) had a reduced shoot length of seedlings. Significant reduction in shoot length of seedlings was also observed in inbred line L-3 treated with fludioxonil+metalaxyl-M and thiametoxam $(\mathrm{M}+\mathrm{Cr})(122.4 \mathrm{~mm})$. Seed of inbred line L-4 treated with fludioxonil+metalaxyl-M and clothianidin $(\mathrm{M}+\mathrm{P})$, fludioxonil+metalaxyl-Mandimidacloprid $(\mathrm{M}+\mathrm{G}), \quad$ fludioxonil+metalaxyl-M and thiametoxam $(\mathrm{M}+\mathrm{Cr})$, fludioxonil + metalaxyl-M and tefluthrin+thiametoxam $(\mathrm{M}+\mathrm{FZ})$ and fludioxonil+metalaxyl-M and fipronil $(\mathrm{M}+\mathrm{Co})$ had significantly greater shoot length of seedlings compared to control.

Root length of seedlings of maize inbred lines ranged between $122.4 \mathrm{~mm}$ and $137.5 \mathrm{~mm}$ in control (Table 6). The significantly greater root length of seedlings was observed in inbred line L-1, treated with fludioxonil+metalaxyl-M and tefluthrin+thiametoxam (M+FZ) $(157.5 \mathrm{~mm})$. Inbred line $\mathrm{L}-2$, treated with fludioxonil+metalaxyl-M (M) (148.1 $\mathrm{mm})$, also had significantly greater root length compared to control $(122.4 \mathrm{~mm})$. Obtained results of inbred lines L-3 and L-4 treated with all tested

Table 4. Abnormal seedlings (\%) of maize inbred lines seed treated with insecticides and a fungicide Tabela 4. Atipični ponici (\%) inbred linija kukuruza tretiranih insekticidima i fungicidom

\begin{tabular}{ccccc}
\hline $\begin{array}{c}\text { Abnormal (\%) seedlings } \\
\text { Atipični (\%) ponici }\end{array}$ & $\begin{array}{c}\text { Inbred line } \\
\mathrm{L}-1\end{array}$ & $\begin{array}{c}\text { Inbred line L-2 } \\
\text { Inbred linija L-2 }\end{array}$ & $\begin{array}{c}\text { Inbred line L-3 } \\
\text { Inbred linija L-3 }\end{array}$ & $\begin{array}{c}\text { Inbred line L-4 } \\
\text { Inbred linija L-4 }\end{array}$ \\
\hline Control/ Kontrola & $2.75 \mathrm{a}$ & $1.75 \mathrm{ab}$ & $2.50 \mathrm{bc}$ & $0.50 \mathrm{~d}$ \\
$\mathrm{M}$ & $2.75 \mathrm{a}$ & $0.75 \mathrm{~b}$ & $4.50 \mathrm{~b}$ & $3.25 \mathrm{~cd}$ \\
$\mathrm{M}+\mathrm{P}$ & $2.50 \mathrm{a}$ & $3.00 \mathrm{ab}$ & $2.75 \mathrm{bc}$ & $0.75 \mathrm{~d}$ \\
$\mathrm{M}+\mathrm{G}$ & $2.00 \mathrm{a}$ & $1.75 \mathrm{ab}$ & $8.75 \mathrm{a}$ & $12.50 \mathrm{a}$ \\
$\mathrm{M}+\mathrm{Cr}$ & $2.50 \mathrm{a}$ & $1.75 \mathrm{ab}$ & $0.00 \mathrm{c}$ & $4.25 \mathrm{bc}$ \\
$\mathrm{M}+\mathrm{FZ}$ & $3.75 \mathrm{a}$ & $4.00 \mathrm{a}$ & $1.50 \mathrm{bc}$ & $7.50 \mathrm{~b}$ \\
$\mathrm{M}+\mathrm{Co}$ & $1.50 \mathrm{a}$ & $1.25 \mathrm{ab}$ & $2.25 \mathrm{bc}$ & $0.00 \mathrm{~d}$ \\
\hline $\mathrm{LSD}$ & 2.82 & 2.04 & 3.83 & 3.15 \\
\hline
\end{tabular}


Table 5. Shoot length $(\mathrm{mm})$ of seedlings of maize inbred lines treated with insecticides and a fungicide Tabela 5. Dužina nadzemnog dela ponika $(\mathrm{mm})$ inbred linija kukuruza tretiranih insekticidima i fungicidom

\begin{tabular}{ccccc}
\hline & $\begin{array}{c}\text { Inbred line L-1 } \\
\text { Inbred linija L-1 }\end{array}$ & $\begin{array}{c}\text { Inbred line L-2 } \\
\text { Inbred linija L-2 }\end{array}$ & $\begin{array}{c}\text { Inbred line L-3 } \\
\text { Inbred linija L-3 }\end{array}$ & $\begin{array}{c}\text { Inbred line L-4 } \\
\text { Inbred linija L-4 }\end{array}$ \\
\hline Control/Kontrola & $126.7 \mathrm{~b}$ & $173.0 \mathrm{a}$ & $151.1 \mathrm{ab}$ & $111.3 \mathrm{~d}$ \\
$\mathrm{M}$ & $116.2 \mathrm{~b}$ & $150.8 \mathrm{~b}$ & $140.1 \mathrm{abc}$ & $124.4 \mathrm{~cd}$ \\
$\mathrm{M}+\mathrm{P}$ & $166.4 \mathrm{a}$ & $113.9 \mathrm{~cd}$ & $157.9 \mathrm{a}$ & $162.5 \mathrm{a}$ \\
$\mathrm{M}+\mathrm{G}$ & $120.4 \mathrm{~b}$ & $123.2 \mathrm{c}$ & $151.8 \mathrm{ab}$ & $133.1 \mathrm{bc}$ \\
$\mathrm{M}+\mathrm{Cr}$ & $121.7 \mathrm{~b}$ & $114.2 \mathrm{~cd}$ & $122.4 \mathrm{c}$ & $140.9 \mathrm{~b}$ \\
$\mathrm{M}+\mathrm{FZ}$ & $130.4 \mathrm{~b}$ & $100.0 \mathrm{~d}$ & $149.9 \mathrm{ab}$ & $154.4 \mathrm{a}$ \\
$\mathrm{M}+\mathrm{Co}$ & $121.0 \mathrm{~b}$ & $161.2 \mathrm{ab}$ & $136.9 \mathrm{bc}$ & $135.9 \mathrm{bc}$ \\
\hline LSD & 16.80 & 19.78 & 13.42 & 13.54 \\
\hline
\end{tabular}

Table 6. Root length $(\mathrm{mm})$ of seedlings of maize inbred lines treated with insecticides and a fungicide Tabela 6. Dužina korena ponika $(\mathrm{mm})$ inbred linija kukuruza tretiranih insekticidima i fungicidom

\begin{tabular}{ccccc}
\hline & $\begin{array}{c}\text { Inbred line L-1 } \\
\text { Inbred linija L-1 }\end{array}$ & $\begin{array}{c}\text { Inbred line L-2 } \\
\text { Inbred linija L-2 }\end{array}$ & $\begin{array}{c}\text { Inbred line L-3 } \\
\text { Inbred linija L-3 }\end{array}$ & $\begin{array}{c}\text { Inbred line L-4 } \\
\text { Inbred linija L-4 }\end{array}$ \\
\hline Control/Kontrola & $129.2 \mathrm{~b}$ & $122.4 \mathrm{~b}$ & $134.6 \mathrm{a}$ & $137.5 \mathrm{a}$ \\
$\mathrm{M}$ & $124.5 \mathrm{~b}$ & $148.1 \mathrm{a}$ & $124.5 \mathrm{a}$ & $143.5 \mathrm{a}$ \\
$\mathrm{M}+\mathrm{P}$ & $131.5 \mathrm{~b}$ & $120.5 \mathrm{~b}$ & $150.1 \mathrm{a}$ & $135.0 \mathrm{a}$ \\
$\mathrm{M}+\mathrm{G}$ & $125.6 \mathrm{~b}$ & $128.4 \mathrm{ab}$ & $153.8 \mathrm{a}$ & $149.5 \mathrm{a}$ \\
$\mathrm{M}+\mathrm{Cr}$ & $128.2 \mathrm{~b}$ & $123.6 \mathrm{~b}$ & $128.0 \mathrm{a}$ & $132.9 \mathrm{a}$ \\
$\mathrm{M}+\mathrm{FZ}$ & $157.5 \mathrm{a}$ & $119.1 \mathrm{~b}$ & $159.9 \mathrm{a}$ & $159.2 \mathrm{a}$ \\
$\mathrm{M}+\mathrm{Co}$ & $133.0 \mathrm{~b}$ & $128.0 \mathrm{ab}$ & $141.4 \mathrm{a}$ & $158.4 \mathrm{a}$ \\
\hline $\mathrm{LSD}$ & 13.61 & 18.59 & 59.60 & 25.05 \\
\hline
\end{tabular}

Table 7. Fresh shoot weight (g) of seedlings of maize inbred lines treated with insecticides and a fungicide Tabela 7. Masa svežeg nadzemnog dela ponika $(\mathrm{g})$ inbred linija kukuruza tretiranih insekticidima i fungicidom

\begin{tabular}{ccccc}
\hline & $\begin{array}{c}\text { Inbred line L-1 } \\
\text { Inbred linija L-1 }\end{array}$ & $\begin{array}{c}\text { Inbred line L-2 } \\
\text { Inbred linija L-2 }\end{array}$ & $\begin{array}{c}\text { Inbred line L-3 } \\
\text { Inbred linija L-3 }\end{array}$ & $\begin{array}{c}\text { Inbred line L-4 } \\
\text { Inbred linija L-4 }\end{array}$ \\
\hline Control/Kontrola & $3.81 \mathrm{c}$ & $5.10 \mathrm{bc}$ & $5.08 \mathrm{~b}$ & $3.56 \mathrm{e}$ \\
$\mathrm{M}$ & $4.90 \mathrm{~b}$ & $5.07 \mathrm{bc}$ & $5.73 \mathrm{ab}$ & $5.14 \mathrm{c}$ \\
$\mathrm{M}+\mathrm{P}$ & $6.31 \mathrm{a}$ & $5.58 \mathrm{ab}$ & $6.08 \mathrm{a}$ & $5.80 \mathrm{a}$ \\
$\mathrm{M}+\mathrm{G}$ & $5.27 \mathrm{~b}$ & $5.67 \mathrm{ab}$ & $5.36 \mathrm{ab}$ & $4.73 \mathrm{~d}$ \\
$\mathrm{M}+\mathrm{Cr}$ & $4.81 \mathrm{~b}$ & $5.84 \mathrm{ab}$ & $5.00 \mathrm{~b}$ & $4.63 \mathrm{~d}$ \\
$\mathrm{M}+\mathrm{FZ}$ & $4.81 \mathrm{~b}$ & $4.58 \mathrm{c}$ & $5.48 \mathrm{ab}$ & $5.75 \mathrm{ab}$ \\
$\mathrm{M}+\mathrm{Co}$ & $4.71 \mathrm{~b}$ & $6.13 \mathrm{a}$ & $6.08 \mathrm{a}$ & $5.39 \mathrm{bc}$ \\
\hline $\mathrm{LSD}_{0.05}$ & 0.86 & 0.78 & 0.74 & 0.37 \\
\hline
\end{tabular}


Table 8. Fresh root weight (g) of seedlings of maize inbred lines treated with insecticides and a fungicide Tabela 8. Masa svežeg korena ponika (g) inbred linija kukuruza tretiranih insekticidima i fungicidom

\begin{tabular}{ccccc}
\hline & $\begin{array}{c}\text { Inbred line L-1 } \\
\text { Inbred linija L-1 }\end{array}$ & $\begin{array}{c}\text { Inbred line L-2 } \\
\text { Inbred linija L-2 }\end{array}$ & $\begin{array}{c}\text { Inbred line L-3 } \\
\text { Inbred linija L-3 }\end{array}$ & $\begin{array}{c}\text { Inbred line L-4 } \\
\text { Inbred linija L-4 }\end{array}$ \\
\hline Control/Kontrola & $1.36 \mathrm{c}$ & $2.06 \mathrm{~b}$ & $1.58 \mathrm{~d}$ & $1.73 \mathrm{~d}$ \\
$\mathrm{M}$ & $2.09 \mathrm{~b}$ & $2.25 \mathrm{~b}$ & $2.27 \mathrm{bc}$ & $2.94 \mathrm{a}$ \\
$\mathrm{M}+\mathrm{P}$ & $2.24 \mathrm{~b}$ & $3.21 \mathrm{a}$ & $3.48 \mathrm{a}$ & $2.06 \mathrm{~cd}$ \\
$\mathrm{M}+\mathrm{G}$ & $2.29 \mathrm{~b}$ & $3.21 \mathrm{a}$ & $2.42 \mathrm{~b}$ & $2.27 \mathrm{bc}$ \\
$\mathrm{M}+\mathrm{Cr}$ & $3.40 \mathrm{a}$ & $1.27 \mathrm{c}$ & $2.27 \mathrm{bc}$ & $2.38 \mathrm{bc}$ \\
$\mathrm{M}+\mathrm{FZ}$ & $3.26 \mathrm{a}$ & $2.41 \mathrm{~b}$ & $1.98 \mathrm{c}$ & $2.54 \mathrm{~b}$ \\
$\mathrm{M}+\mathrm{Co}$ & $3.01 \mathrm{a}$ & $2.11 \mathrm{~b}$ & $3.32 \mathrm{a}$ & $2.37 \mathrm{bc}$ \\
\hline $\mathrm{LSD}_{0.05}$ & 0.47 & 0.36 & 0.35 & 0.42 \\
\hline
\end{tabular}

preparations showed no significant differences compared to control.

Inbred lines L-1 and L-4 treated with all preparations included in this study had significantly greater mass of fresh shoot of seedlings compared to control (Table 7). A significantly greater fresh shoot weight of seedlings was observed in inbred line L-2 treated with fludioxonil+metalaxyl-M and fipronil (M+Co) (6.13 g). Inbred line L-3, treated with fludioxonil+metalaxyl-M and clothianidin $(\mathrm{M}+\mathrm{P})$ and fludioxonil+metalaxyl-M and fipronil $(\mathrm{M}+\mathrm{Co})$, also had a greater fresh shoot weight of seedlings.

Inbred lines L-1 and L-3 treated with all preparations included in this study had a significant greater fresh root weight of seedlings compared to control (Table 8). All applied preparations resulted in an increase of fresh root weight of inbred line L-4 seedlings, but greater mass of this parameter in inbred line L-4 treated with fludioxonil+metalaxyl-M and clothianidin $(\mathrm{M}+\mathrm{P})(2.06 \mathrm{~g})$ was not significant. Inbred line L-2 treated with fludioxonil+metalaxyl-M and clothianidin $(\mathrm{M}+\mathrm{P})$ and fludioxonil + metalaxyl-M and imidacloprid $(\mathrm{M}+\mathrm{G})(3.21 \mathrm{~g})$ had a significant greater fresh root weight of seedlings. Also a significant decrease of fresh root weight of seedlings was observed in inbred line L-2 treated with fludioxonil+metalaxyl-M and thiametoxam $(\mathrm{M}+\mathrm{Cr})(1.27 \mathrm{~g})$.

\section{Discussion}

The effects of applied preparations on seed quality parameters depending on the varietal susceptibility of maize inbred lines were shown in this study. Inbred line L-1 proved to be the most tolerant genotype with respect to the applied seed treatment, because there were no significant differences observed in germination compared to the control. The fludioxonil+metalaxyl-M and thiametoxam had no effect on the seed quality of L-1, L-2 and L-3, but reduction in germination energy and germination were observed, as well as the increased percentage of abnormal seedlings in inbred line L-4. Many researchers have shown that thiametoxam stimulates rapid germination by stimulating higher enzymatic activity which increases both primary and secondary metabolism and thus provides better germination and more uniform growth for many crops (Clavijo 2008, Cataneo 2008). Thiametoxam increases viability, accumulation of biomass, root development and rate of photosynthesis (Cataneo 2008).

Seed of inbred lines L-3 and L-4 treated with fludioxonil+metalaxyl-M and imidacloprid, resulted in significantly lower germination energy and germination, and the increased percentage of abnormal seedlings.

These results are in accordance with the results of Mrda et al. (2009) on sunflower seed, although there are opposite results which indicate that imidacloprid had no effect on the germination of seeds of maize (Bittencourt et al. 2000, Dan et al. 2012). Increased percentage of abnormal seedlings can be explained by the fact that application of imidacloprid at particular concentrations can lead to disturbances in the metabolism, resulting in the appearance of abnormal seedlings (Ebel et al. 2000).

Quality of maize inbred lines seed treated 
with preparations based on active ingredients fludioxonil+metalaxyl-M and fipronil was not significantly different compared with the control. Cox et al. (2007) showed that the use of preparation with the active ingredient fipronil caused no phytotoxic effect on the growth and development of maize.

Application of fungicide fludioxonil+metalaxyl-M to seed of inbred lines L-3 and L-4 led to a reduction in germination energy and germination, which is opposite to the results of Dragičević et al. (2011). Matijević (1990) stressed out the importance of choosing the optimal fungicide dose, as those lethal for mycelium are frequently high enough and therefore toxic to the seeds, and can affect its germination energy, germination and later on plant growth.

Shoot length of maize inbred lines seedlings treated with tested preparations varied to some extent. Application of imidacloprid and thiametoxam significantly reduced shoot length of seedlings of maize inbred line L-2. Negative influence of these preparations was also noted in black bean seed (Guimarães et al. 2005). Conversely, Almeida et al. (2013) obtained results which indicate the positive influence of thiametoxam on shoot development of rice seedlings.

All tested preparations had no negative effect on root length of maize inbred lines seedlings. A significant increase in root length was observed when seeds were treated with tefluthrin+thiametoxam. Nunes (2006) assessed that the effect of thiametoxam on seed germination produced plants with greater root growth. The obtained results showed no differences in root length of seedlings when seed was treated with the preparation based on the active ingredient fipronil, which is opposite to the results of Silveira et al. (2001).

In general, all tested preparations increased mass of fresh shoot and root of maize inbred lines seedlings. Only seed of inbred line L-2 treated with thiametoxam had a significantly reduced mass of fresh root of seedlings compared to control which is opposite to results achieved by Dragičević et al. (2011) and Cataneo (2008).

Various results can be explained by the fact that some effects of the applied preparations depend on the genetic composition of species and varietal specificity of the tested inbred lines.

\section{Conclusions}

According to the obtained results the following could be concluded:

- The application of all tested preparations to the seed of inbred line L-1 did not lead to significant changes in seed quality compared to control.

- Fludioxonil+metalaxyl-M (M) and fludioxonil+metalaxyl-M and imidacloprid $(M+G)$ decreased the germination energy and germination of inbred line L-3 and L-4 and significant increase in abnormal seedlings was observed only in application of fludioxonil + metalaxil-M and imidacloprid $(\mathrm{M}+\mathrm{G})$.

- Fludioxonil+metalaxyl-M

and tefluthrin+thiametoxam $(\mathrm{M}+\mathrm{FZ})$ decreased the germination energy and germination of inbred line L-2 and L-4, and a significant increase in abnormal seedlings was recorded only in the inbred line L-4.

- The application of fludioxonil+metalaxyl-M and thiametoxam $(\mathrm{M}+\mathrm{Cr}$ ) affected seed quality parameters of inbred line L-4.

- The application of fludioxonil+metalaxyl-M and fipronil $(\mathrm{M}+\mathrm{Co})$ did not affect the germination energy, seed germination, abnormal seedlings and shoot lenght of inbred lines.

- The application of all tested preparations on the seed of inbred lines L-3 and L-4 led to a significant increase in seedling root length.

- The application of all tested preparations on the seed of inbred lines L-1 and L-3 led to a significant increase in fresh shoot and root weight of seedlings. 


\section{References}

Almeida, A.S., Villela, F.A., Nunes, J.C., Meneghello, G.E \& Jauer A. (2013). Thiametoxam: An Insecticide that Improve Seed Rice Germination at Low Temperature in Insecticides. In: Stanislav Trdan (ed.), Development of Safer and More Effective Technologies. (pp. 417-426). doi:10.5772/53207

Bittencourt, S.R.M., Fernandes, M.A., Ribeiro, M.C., \& Vieira R.D. (2000). Desempenhovde sementes de milho tratadas com inseticidas sistêmicos. Revista Brasilieira de Sementes, 22(2), 86-93.

Bradley, C.A. (2008). Effect of fungicide treatments on stand establishment, seedling disease and yield of soybean in North Dakota. Plant Disease, 92, 120-125.

Bradley, C.A., Wax, L.M., Ebelhar, S.A., Bollero, G.A., \& Pedersen, W.L. (2001). The effect of fungicide seed protectnats, seedling rates, and reduce rates of herbicides on no-till soybean. Crop Protection, 20, 615-622.

Cataneo, A.C. (2008). Ação do Tiametoxam sobre a germinação de sementes se soja (Glycine max L.): Enzimas envolvidas na mobilização de reservas e na proteção contra situaçã de estresse (deficiência hidrica, salinidade e presença de aluminio). In D.L. Gazzoni (Ed.), Tiamethoxam: Uma revolução na agricultura brasileira. (pp. 123-192).

Clavijo, J. (2008). Tiametoxam: Um nuevo concepto em vigor y productividad. (p. 196). Bogotá, Colômbia.

Cox, W.J., Shields, E., \& Cherney, J.H. (2007). The Effects of Clothianidin Seed Treatments on Corn Growth following Soybean. Crop. Sci., 47, 2482-2485.

Dan, L.G.M., Dan, H.A., Braccini, A.L., Barrosp, A.L.L., Ricci, T.T., Piccinin, G.G., \& Scapim, C.A. (2012). Insecticide Treatment and Physiological Quality of Seeds. In P. Farzana (Ed.), Insecticides - Advances in Integrated Pest Management. doi:10.5772/29102

Dragičević, V., Gošić-Dondo, S., Jug, I., Srdić, J., \& Sredojević, S. (2011). The influence of seed treatments on germination and initial growth of maize seedlings. In: Proc. 46th Croatian and 6th international Symposium on Agriculture. Opatia. 654657.
Ebel, R.C., Wallace, B., \& Elkins, C. (2000). Phytotoxicity of the Systemic Insecticide imidacloprid on tomato and Cucumber in the Greenhouse. Hort Techn, 10(1), 144-147.

Galli, J.A., Fassel, S.A., \& Panizzi, R.C. (2005). Effect of Fusarium graminearum and infection index on germination and vigor of maize seeds. Fitopatologia Brasileira, 3, 470-474.

Govender, V. (2008). Vigour of fungicide-treated and untreated maize seed following storage. (pp. 113-131). University of Pretoria. Doctoral thesis.

Guimarães R. N. et al. (2005). Efeito do tratamento de sementes com inseticidas na emergência altura de plântulas de feijão. In: Congresso Nacional De Pesquisa De Feijão, Goiânia, 8, 94-99.

International Seed Testing Association. (2009). International rules for seed testing. Switzerland.

Jocković, Đ., Boćanski, J., Popov, R., Malidža, G., Nastasić, A., \& Đalović, I. (2011). Maize Seed Production. In: M. Milošević \& B. Kobiljski (Eds.), Semenarstvo II. Novi Sad: Institute of Field and Vegetable Crops. pp. 91-195.

Matijević, D. (1990). Phytopharmacologic value of fungicides seed treatment in suppression of pathogen Pyrenophora gramineae Ibo and Kuriba. Novi Sad: University of Novi Sad, Faculty of Agriculture. Doctoral dissertation.

Mrđa, J., Ostojić, B., Radić, V., Prole, S., Jokić, G., Butaš, D., \& Miklič, V. (2009). The effect of different storage conditions on the germination of treated hybrid sunflower seeds. Ratar. Povrt., 46(1), 63-71.

Nunes, J. C.(2006). Bioativador de plantas, Seeds News. Pelotas, 3(5), 30-31.

Sekulić, R., Kereši, T., \& Radonjić, K. (2005). Some economically important pests of sugar beet and corn - condition, prognosis and potential control. Ratar. Povrt., 41, 521-531.

Silveira, R.E., Maccari, M., \& Marquezi C.F. (2001). Avaliação do efeito de inseticidas aplicados via tratamento de sementes sobre o desenvolvimento de raizes de milho, na proteção de pragas do solo. In: Reunião Sul-Brasileira Sobre Pragas De Solo, 8., Londrina. Anais. Londrina: embrapa Soja, 246-249.

SFRY (1987). Rule on seed quality testing of agricultural plants. Official gazttte SFRJ, 47.

Stevanović, V., Inđić, D., \& Knežević, B. (2009). Effect of fungicides on seed germination of barley. Pestic. fitomed, 24, 3541. doi:10.2298/PIF0901035S

\title{
Uticaj tretiranja semena neonikotinoidima na kvalitet semena inbred linija kukuruza
}

\author{
Gordana Tamindžić • Zorica Nikolić • Raško Popov • Dušica Jovičić • \\ Gordana Zdjelar • Vesna Župunski • Maja Ignjatov
}

Sažetak: S obzirom da je ujednačeno klijanje i nicanje u polju od velike važnosti za postizanje visokih prinosa uz obezbeđenje dobrog kvaliteta semena, postavlja se pitanje uticaja fungicidnih i insekticidnih preparata za tretiranje semena na kvalitet semena. Cilj istraživanja je bio da se utvrdi efekat primene kombinacija pet insekticidnih i jednog fungicidnog preparata na energiju klijanja i klijavost semena četiri inbred linije kukuruza. Primenjeni preparati su različito uticali na kvalitet semena u zavisnosti od genetske kompozicije inbred linija kukuruza. Inbred linija L-1 se izdvaja kao najtolerantnija, s obzirom da nisu zabeležena značajna odstupanja u pogledu kvaliteta semena kod svih primenjenih preparata u poređenju sa kontrolom, dok je kod najosetljivijeg genotipa, inbred linije L-4, zabeleženo značajno smanjenje energije klijanja i klijavosti semena tretiranog preparatima na bazi aktivne materije fludioksonil+metalaksil-M $(\mathrm{M})$, fludioksonil+metalaksil-M i imidakloprid $(\mathrm{M}+\mathrm{G})$, fludioksonil+metalaksil-M i tiametoksam $(\mathrm{M}+\mathrm{Cr})$ i fludioksonil+metalaksil-M teflutrin+tiametoksam $(\mathrm{M}+\mathrm{FZ})$. Rezultati ovog istraživanja ukazuju na važnost odabira najbolje kombinacije pesticida za određene genotipove, kako bi se obezbedila potpuna zaštita useva, a istovremeno se postigli visoki prinosi.

Ključne reči: fungicid, inbred linije kukuruza, insekticid, klijavost, kukuruz, neonikotinoid, seme, tretiranje semena 